\title{
HUBUNGAN ANTARA HbA1c DAN KADAR LIPID SERUM DENGAN DERAJAT BERAT RETINOPATI DIABETIKA
}

\section{THE CORRELATION BETWEEN HbA1C AND SERUM LIPID LEVEL WITH THE SEVERITY OF DIABETIC NEUROPATHY}

\author{
Safaruddin Refa, Nadia Artha Dewi \\ Bagian / SMF Mata Fakultas Kedokteran Universitas Brawijaya / RSU dr. Saiful Anwar Malang
}

\begin{abstract}
Diabetic retinopathy is a leading cause of blindness in industrial world and is rapidly becoming an important cause in developing countries. Many factors related with the severity of diabetic retinopathy, such as HbA1C and serum lipid. The study wants to know whether those factors have any correlation with the severity of diabetic retinopathy or not. The objective this study was to determine the correlation between $\mathrm{HbA1c}$ and serum lipid with the severity of diabetic retinopathy. An analytic cross sectional observational research had been done at Saiful Anwar hospital. The samples (diabetic retinopaty patients) were taken with consecutive sampling. These patient underwent funduscopy, fundus photography, laboratory examination including $\mathrm{HbA1c}$, serum lipid (total serum cholesterol, LDL, HDL, triglycerides), and blood glucose. These patient were questioned about risk factors previously determined by the authors. The laboratory findings were thease are compared to the severity of diabetic retinopathy. Patient were classified into 2 group, mild and severe diabetic retinopathy. A total of 38 patients were selected, consisted of 20 males, 18 females. Nineteen patients had mild diabetic retinopathy, and the rests had severe diabetic retinopathy. Logistic regression analysis found that there was a significant correlation between $\mathrm{HbA1c}$ with the severity of diabetic retinopathy $(p=0.017)$. An increases of $1 \%$ in $\mathrm{HbA1c}$ will result in two folds $(1,995)$ increases, in probability of severity of diabetic retinopathy. The cut off value for $\mathrm{HbA1c}$ was $8.147 \%$. The variables of total serum cholesterol $(p=0.338), L D L(p=0.241), H D L(p=0.685)$, and triglycerides $(p=0.127)$ were not significant.. There was significant correlation between $\mathrm{HbA1c}$ with the severity of diabetic retinopathy. There was no significant correlation of serum lipid with the severity of diabetic retinopathy. The higher level HbA1c influences the severity of diabetic retinopathy.
\end{abstract}

Key words : HbA1c, serum lipid, diabetic retinopathy

\section{PENDAHULUAN}

Retinopati diabetika merupakan salah satu komplikasi mikrovaskular yang terjadi pada mata penderita Diabetes Mellitus (DM) dan merupakan penyebab kebutaan nomor satu di negara maju $(1,2)$. Prevalensi retinopati diabetika tidak sama pada tiap negara. Di Iceland, prevalensi retinopati diabetika pada penderita DM tipe 1 adalah 52\% (3) Di Indonesia prevalensi retinopati diabetika sebanyak $27,2 \%$ (2). Di Amerika, angka kebutaan akibat DM mencapai $12 \%(4,5)$. Kebutaan pada retinopati diabetika disebabkan oleh berbagai faktor yang berhubungan dengan timbulnya maupun perkembangan retinopati diabetika $(2,6)$. Perkembangan tersebut dapat dilihat melalui gambaran fundus, pasien retinopati diabetika ringan, yaitu non proliferatif (NPDR) sampai proliferatif

Jurnal Kedokteran Brawijaya, Vol. XXI, No.3, Desember 2005

Korespondensi: Nadia Artha Dewi; Bagian/SMF Mata FK Unibraw / RSSA Malang; Jl. Jaksa agung Suprapto 2 Malang, Telp :(0341)341945, Fax : :(0341)341945

Email: nadophthalmic@yahoo.com;

matamalangrssa@yahoo.com
(PDR) $(6,7)$.

Beberapa faktor yang diketahui berhubungan dengan perkembangan derajat berat retinopati diabetika, antara lain lamanya menderita DM, keadaan hiperglikemia yang kronis, dislipidemia, hipertensi sistemik, kehamilan, dan merokok (5,6,8-14). Dari semua faktor resiko, keadaan hiperglikemia kronis akibat kontrol glukosa yang buruk merupakan penyebab tersering dari timbulnya retinopati pada DM $(1,7,15,16)$.

Berdasarkan fakta-fakta diatas, mengetahui faktor yang berpengaruh pada derajat berat retinopati diabetika sangat penting. Pada penelitian ini faktor resiko yang akan diteliti adalah faktor resiko yang merupakan penyebab tersering, yaitu keadaan hiperglikemia kronis yang diukur kontrolnya melalui pemeriksaan hemoglobin $\mathrm{A} 1 \mathrm{c}(\mathrm{HbA} 1 \mathrm{c})$, dan faktor resiko yang hendak dibuktikan peranannya, yaitu kadar lipid serum yang terdiri dari kadar kolesterol total, trigliserida, Low Density Lipoprotein (LDL), dan High Density Lipoprotein (HDL). Bila ternyata tingginya kadar $\mathrm{HbA1C}$ dan terdapatnya keadaan dislipidemia yaitu tingginya kadar kolesterol total, trigliserida, LDL, dan turunnya kadar HDL ikut meningkatkan derajat berat 
retinopati diabetika, maka keadaan hiperglikemia dan dislipidemia tersebut harus diturunkan sehingga angka kebutaan pada penderita akibat DM dapat diperlambat.

\section{METODE}

Subyek penelitian adalah penderita retinopati diabetika yang datang ke poliklinik Vitreoretina RSUD dr. Saiful Anwar. Kriteria inklusi meliputi penderita yang belum pernah diterapi fotokoagulasi laser sebelumnya, usia tidak kurang dari 15 tahun, tidak didapatkan kekeruhan media refraksi yang dapat mengganggu visualisasi fundus, tidak didapatkan penyakit vaskular lain pada retina, tidak menderita hipertensi sistemik, tidak sedang hamil, dan setuju menandatangani informed consent dan surat persetujuan ikut penelitian.

Pemeriksaan mata dilakukan dengan slit lamp, pemeriksaan tajam penglihatan dengan koreksi, pemeriksaan fundus menggunakan oftalmoskop direk (Neitz $B X \forall)$, indirek (Keeler Instruments, Inc), dan foto fundus (Topcon FD-31A) dalam keadaan pupil midriasis menggunakan tropicamid $1 \%$.

Anamnesis pada penderita ditanyakan mengenai lama menderita DM, penggunaan obat DM dan anti kolesterol, diet yang dilakukan, dan apakah penderita merokok atau tidak.

Penderita diklasifikasikan menjadi 2 kelompok, yaitu retinopati diabetika ringan dan berat. Pengelompokkan ini berdasarkan derajat berat retinopati diabetika menurut Early Treatment Diabetic Retinopathy Study (ETDRS), retinopati diabetika ringan meliputi kriteria NPDR sangat ringan sampai ringan, yaitu yang menunjukkan tanda-tanda pada retina berupa mikroaneurisma, dan atau perdarahan intraretinal, dan hard eksudat. Retinopati diabetika berat adalah retinopati diabetika ringan ditambah tanda-tanda NPDR derajat sedang sampai PDR lanjutan (advanced) yang meliputi :cotton wool spot, intraretinal microvascular abnormality (IRMA), vena yang berkelok-kelok, neovaskularisasi, perdarahan preretina, perdarahan badan kaca, proliferasi jaringan fibrosa, ablasio retina $(6,7)$. Masing-masing komponen diatas mempunyai skor 1 , yaitu kriteria retinopati diabetika ringan ditegakkan bila mempunyai skor $\leq 3$ pada masing-masing mata, dan retinopati diabetika berat ditegakkan bila mempunyai skor > 3 pada salah satu atau masing-masing mata. Untuk kepentingan statistik, penderita yang masuk kelompok pertama, yaitu retinopati diabetika ringan masuk dalam kriteria 0 , dan kelompok kedua yaitu retinopati diabetika berat masuk dalam kriteria 1.

Pada tiap penderita diperiksa $\mathrm{HbA1c}$, dan kadar lipid serum. HbA1c merupakan kadar hemoglobin terglikosilasi, nilai normalnya adalah 3-6\% (17). Kadar lipid serum meliputi kolesterol total (nilai normal $<200 \mathrm{mg} / \mathrm{dl}$ ), LDL (nilai normal $<130 \mathrm{mg} / \mathrm{dl}$ ), HDL (nilai normal $>55 \mathrm{mg} / \mathrm{dl}$ ), dan trigliserida (nilai normal $<160 \mathrm{mg} / \mathrm{dl}$ ) (6). Glukosa darah puasa (GD1) dan 2 jam post pandrial (GD2) juga diperiksa. Disebut hipertensi bila pada saat pemeriksaan terdapat tekanan darah sistolik $>140 \mathrm{mmHg}$ dan atau tekanan darah diastolik > $100 \mathrm{mmHg}$, maupun pernah didiagnosis oleh dokter menderita hipertensi (6).

Analisis yang dipakai untuk mengetahui hubungan antara $\mathrm{HbA} 1 \mathrm{c}$ dan kadar lipid serum menggunakan analisis regresi logistik.

\section{HASIL PENELITIAN}

Didapatkan 38 penderita retinopati diabetika yang telah memenuhi kriteria inklusi, dengan 19 orang menderita retinopati diabetika ringan, dan sisanya menderita retinopati diabetika berat. Variasi usia penderita adalah 36 sampai 73 tahun. Pada retinopati diabetika ringan usia berkisar antara 49 sampai 73 tahun (rata-rata $58,32 \pm 7,52$ tahun), sedangkan retinopati diabetika berat antara 36 sampai 68 tahun (rata-rata $53,37 \pm 7,80$ tahun). Dari anamnesa didapatkan semua sampel mendapatkan pengobatan DM secara rutin, tanpa dibedakan jenis pemberiannya (oral maupun insulin). Data deskriptif penderita seperti tajam penglihatan, kadar gula darah, dan lama menderita DM disajikan dalam Tabel 1 dan 2. Distribusi jenis kelamin, perilaku merokok dan diet digambarkan pada Tabel 3,4, dan 5 .

Tabel 1. Karakteristik Deskriptif Penderita Retinopati Diabetika Ringan

\begin{tabular}{lccccc}
\hline & $\mathrm{N}$ & Minimum & Maksimum & Rata-rata & Std. Deviasi \\
\hline Tajam penglihatan OD ( logMAR) & 19 & 0,00 & 1,18 & 0,24 & 0,34 \\
Tajam penglihatan OS ( logMAR) & 19 & 0,00 & 0,08 & 0,30 & 0,34 \\
GD1 (Mg/dl) & 19 & 69 & 324 & 157,79 & 70,77 \\
GD2 (Mg/dl) & 19 & 123 & 470 & 221,63 & 94,07 \\
Lama DM (tahun) & 19 & 1 & 20 & 6,37 & 6,27 \\
\hline
\end{tabular}

Keterangan: OD : Oculi Dextra

OS : Oculi Sinistra

GD1: Glukosa darah Puasa

GD2: Glukosa darah 2 jam post pandrial

DM : Diabetes Mellitus 
Tabel 2. Karakteristik Deskriptif Penderita Retinopati Diabetika Berat

\begin{tabular}{lccccc}
\hline & $\mathrm{N}$ & Minimum & Maksimum & Rata-rata & Std. Deviasi \\
\hline Tajam penglihatan OD ( logMAR) & 19 & 0,08 & 1,48 & 0,82 & 0,42 \\
Tajam penglihatan OS ( logMAR) & 19 & 0,00 & 1,78 & 0,68 & 0,53 \\
GD1 (Mg/dl) & 19 & 72 & 300 & 154,53 & 59,30 \\
GD2 (Mg/dl) & 19 & 134 & 491 & 224,95 & 95,31 \\
Lama DM (tahun) & 19 & 1 & 20 & 8,00 & 6,54 \\
\hline
\end{tabular}

Keterangan: OD : Oculi Dextra

OS : Oculi Sinistra

GD1: Glukosa darah Puasa

GD2: Glukosa darah 2 jam post pandrial

DM : Diabetes Mellitus

Tabel 3. Distribusi Jenis Kelamin Penderita

\begin{tabular}{lcc}
\hline & Retinopati diabetika ringan & Retinopati diabetika berat \\
\hline Laki-laki & $10(52,63 \%)$ & $10(52,63 \%)$ \\
Perempuan & $9(47,36 \%)$ & $9(47,36 \%)$ \\
Jumlah & $19(100 \%)$ & $19(100 \%)$ \\
\hline
\end{tabular}

Tabel 4. Distribusi Perilaku Merokok Penderita

\begin{tabular}{lcc}
\hline & Retinopati diabetika ringan & Retinopati diabetika berat \\
\hline Merokok & $3(15,78 \%)$ & $3(15,78 \%)$ \\
Tidak merokok & $16(84,22 \%)$ & $16(84,22 \%)$ \\
\hline Jumlah & $19(100 \%)$ & $19(100 \%)$ \\
\hline
\end{tabular}

Tabel 5. Distribusi Perilaku Diet Penderita

\begin{tabular}{lcc}
\hline & Retinopati diabetika ringan & Retinopati diabetika berat \\
\hline Diet & $12(63,16 \%)$ & $15(78,94 \%)$ \\
Tidak diet & $7(36,84 \%)$ & $4(21,06 \%)$ \\
\hline Jumlah & $19(100 \%)$ & $19(100 \%)$ \\
\hline
\end{tabular}

Hubungan antara $\mathrm{HbA} 1 \mathrm{c}$ dan kadar lipid serum terhadap derajat berat retinopati diabetika dianalisis menggunakan regresi logistik. Hasil dianggap signifikan bila $p<0,05$. Hubungan yang signifikan ditemukan antara $\mathrm{HbA1c}$ dengan derajat berat retinopati diabetika $(p=0,017)$. Tidak terdapat hubungan yang signifikan pada semua komponen kadar lipid serum yaitu kolesterol total, LDL, $\mathrm{HDL}$, dan trigliserida terhadap derajat berat retinopati diabetika (Tabel 6).

Dari perhitungan analisis regresi logistik ditemukan bahwa pada penderita yang mengalami peningkatan $\mathrm{HbA1c}$, kemungkinan penderita tersebut masuk kedalam retinopati diabetika derajat berat adalah 1,995 kali (2 kali) lipat.
Tabel 6. Hasil Analisis Regresi Logistik HbA1c dan Kadar Lipid Serum

\begin{tabular}{lccccc}
\hline & $\begin{array}{c}\text { Koefisien } \\
\text { (B) }\end{array}$ & $\begin{array}{c}\text { Salah } \\
\text { baku }\end{array}$ & Wald & P-value & Exp (B) \\
\hline HbA1c & 0,691 & 0,289 & 5,728 & 0,017 & 1,995 \\
\hline Kolesterol total & 0,040 & 0,042 & 0,918 & 0,338 & 1,041 \\
\hline LDL & $-0,049$ & 0,042 & 1,372 & 0,241 & 0,952 \\
\hline HDL & $-0,016$ & 0,040 & 0,165 & 0,685 & 0,984 \\
\hline Trigliserida & $-0,021$ & 0,014 & 2,334 & 0,127 & 0,980 \\
\hline Konstanta & $-4,053$ & 3,239 & 1,566 & 0,211 & 0,017 \\
\hline
\end{tabular}

Dari hasil analisis tersebut, dilakukan analisis tersendiri terhadap $\mathrm{HbA} 1 \mathrm{c}$ saja. Hal tersebut digunakan untuk mencari nilai tengah $\mathrm{HbA} 1 \mathrm{c}$, nilai tengah ini menentukan kemungkinan penderita jatuh kearah retinopati diabetika derajat ringan atau berat (cut-off). Nilai cut-off yang diperoleh yaitu $8,147 \%$. 


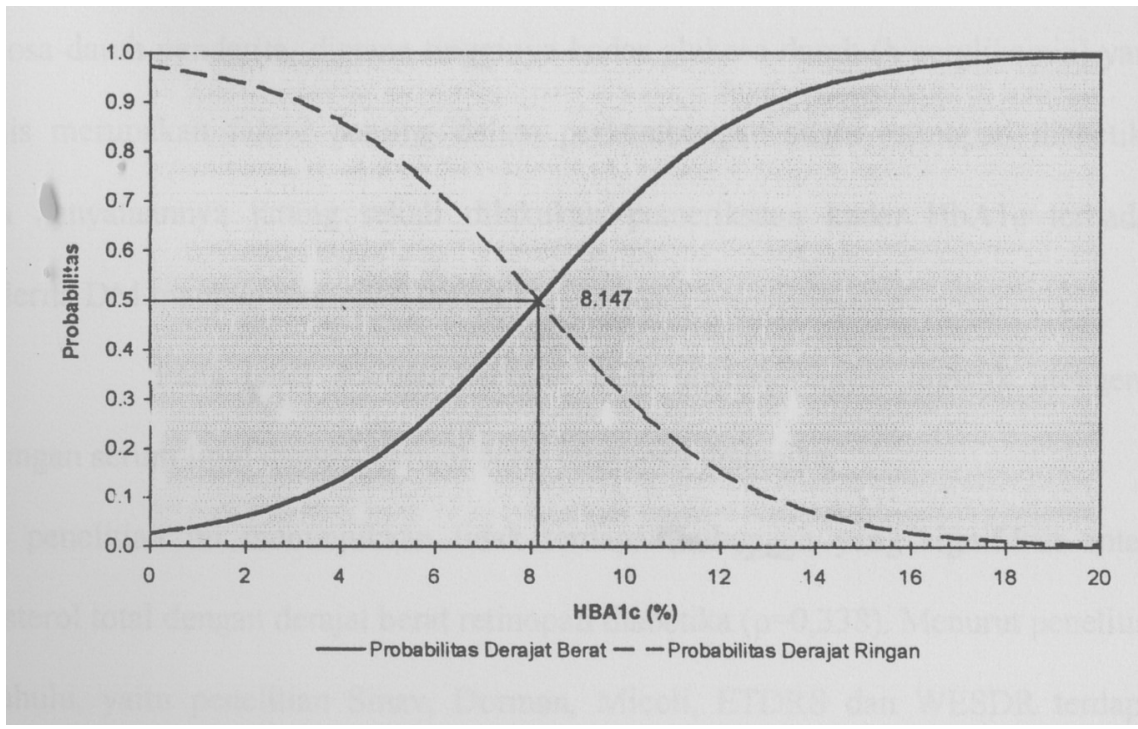

Gambar 1. Nilai cut-off HbA1c

\section{DISKUSI}

Pada penelitian ini ditemukan ada hubungan antara $\mathrm{HbA1c}$ dengan derajat berat retinopati diabetika. Tingginya kadar $\mathrm{HbA} 1 \mathrm{c}$ akan memberikan kemungkinan lebih besar untuk jatuh dalam keadaan retinopati diabetika derajat berat. Hal ini sesuai dengan beberapa penelitian yang terdahulu yang menunjukkan peranan $\mathrm{HbA} 1 \mathrm{c}$ terhadap retinopati diabetika $(6,9-11,18,19)$.

Hasil nilai tengah (cut-off) pada penelitian ini menunjukkan penderita dapat jatuh ke arah retinopati diabetika derajat berat pada kadar $\mathrm{HbA} 1 \mathrm{c}$ lebih dari $8,147 \%$. Beberapa penelitian terdahulu menunjukkan hasil yang berbeda. Penderita yang didiagnosis DM sebelum usia 30 tahun, yang mempunyai kadar $\mathrm{HbA} 1 \mathrm{c}$ lebih dari 13,5\% lebih besar kemungkinannya untuk menderita retinopati diabetika proliferatif dibandingkan dengan penderita yang mempunyai kadar $\mathrm{HbA1c}$ kurang dari 13,5 \% (6,911,18,19). Menurut data dari Diabetes Control and Complications Trial (DCCT), Kunamoto, dan United Kingdom Prospective diabetes Study (UKPDS), setiap penurunan $\mathrm{HbA} 1 \mathrm{C}$ sebesar $1 \%$ akan menurunkan komplikasi mikrovaskular dan makrovaskular. Selain itu menurut Stratton, penurunan komplikasi DM akan terlihat bila kadar $\mathrm{HbA} 1 \mathrm{c}$ dibawah $6,5 \% .{ }^{20}$ Selanjutnya, pada penderita retinopati diabetika yang kontrol gula darahnya kurang memadai, perkembangan retinopatinya akan berlangsung lebih cepat dibandingkan dengan mereka yang kadar gula darahnya terkontrol dengan baik $(6,10,11,18-24)$.

$\mathrm{HbA} 1 \mathrm{c}$ merupakan suatu faktor penting yang berpengaruh terhadap derajat berat retinopati diabetika. Hal ini disebabkan karena $\mathrm{HbA} 1 \mathrm{c}$ merupakan suatu petanda untuk mengetahui kontrol kadar glukosa darah penderita, yaitu mencerminkan rata-rata kadar glukosa darah seharihari (21). HbA1c merupakan $\mathrm{Hb}$ yang terglikosilasi, terbentuk bila glukosa dalam darah menempel pada hemoglobin $(\mathrm{Hb})$. HbA1c dianggap sebagai 'quality control test' karena dapat menilai kontrol metabolisme glukosa selama 3 bulan. Hal ini merupakan keunggulan tersendiri dibanding pemeriksaan kadar glukosa darah puasa (GD1) maupun post pandrial (GD2) karena dapat mengalami fluktuasi tergantung dari makanan dan pengobatan dengan obat anti DM $(6,11,20)$.

Pada orang normal, $\mathrm{Hb}$ yang terglikosilasi sebanyak $3-6 \%$. Bila terdapat keadaan DM, yaitu kadar glukosa darah tinggi (hiperglikemia), maka $\mathrm{Hb}$ yang terglikosilasi lebih banyak lagi $(11,17,20,21)$. Pada kenyataannya jarang sekali dilakukan pemeriksaan kadar $\mathrm{HbA} 1 \mathrm{c}$ terhadap penderita DM maupun retinopati diabetika.

Patogenesis keadaan hiperglikemia dapat menyebabkan gambaran perubahan anatomi pada retinopati diabetika dibagi menjadi tiga, yaitu secara biokimia, hemodinamik, dan endokrin $(25,26)$. Gangguan biokimia adalah faktor yang paling berhubungan. Diduga ada beberapa teori yang dapat dijelaskan, yaitu aldose reduktase-sorbitol (jalur polyol), teori glikosilasi (advanced glycation end product), teori reactive oxygen intermediate (ROI), dan teori protein kinase C (PKC) (1,27-31). Pada glukosa darah yang normal, aktifitas jalur ini tidak mempunyai makna yang berarti karena afinitasnya pada glukosa rendah. Dengan demikian aktifitas jalur ini mempunyai arti yang signifikan pada glukosa darah yang tinggi $(25,27)$.

Faktor lain yang diduga mempengaruhi perkembangan retinopati diabetika adalah pengaruh dari 
dislipidemia. Dislipidemia ini dapat berupa meningkatnya kadar kolesterol total, LDL, trigliserida, maupun menurunnya kadar $\operatorname{HDL}(6,8,32,33)$. Patogenesis dislipidemia dapat menyebabkan perkembangan retinopati diabetika masih belum jelas (34). Hiperkolesterolemia diduga berhubungan dengan aktivasi sel endotel yang ditujukkan dengan adanya stress oksidatif, dan peningkatan adhesi lekosit yang menyebabkan perubahan fungsi sel endotel. Hubungan antara hiperlipidemia terhadap terbentuknya hard eksudat masih belum jelas. Diduga pada hiperlipidemia terjadi peningkatan kekentalan darah dan perubahan sistim fibrinolitik sehingga pembentukan hard eksudat. Peranan trigliserida dalam membran sel menyebabkan perubahan permeabilitas membran dan kebocoran plasma. Hal ini menyebabkan perdarahan dan edema retina $(34,35,36)$.

Diabetes Control and Complications Trial/ Epidemiologi of Diabetes Interventions and Complications Study (DCCT/ EDIC) mengatakan bahwa ada hubungan antara trigliserida dengan derajat berat retinopati diabetika, namun tidak demikian halnya dengan $\operatorname{HDL}(5,37)$.

Penelitian lain menunjukkan hasil yang bertentangan. Menurut Sinav kadar kolesterol total, LDL dan HDL berhubungan dengan retinopati diabetika proliferatif, namun tidak demikian dengan kadar trigliserida $(6,34)$. United Kingdom Prospective Diabetes Study (UKPDS) menemukan bahwa tidak ada hubungan antara kadar trigliserida dan LDL dengan perkembangan derajat berat retinopati diabetika (6).

Dalam penelitian ini tidak ditemukan hubungan yang signifikan antara kadar lipid serum dengan derajat berat retinopati diabetika. Hal ini dapat disebabkan oleh patogenesis yang belum jelas, perbedaan metode penelitian, dan kadar lipid serum yang mengalami fluktuasi, tergantung dari pengobatan dan makanan yang dikonsumsi sebelum pemeriksaan laboratorium dilakukan (38). Kelemahan pada penelitian ini antara lain adalah sulitnya mendapat keterangan yang akurat mengenai obat yang dikonsumsi selain obat anti DM, sehingga tidak diketahui dengan tepat konsumsi obat anti kolesterol penderita.
Penyebab terbanyak dari menurunnya penglihatan pada penderita DM adalah edema macula (6-8). Pada penelitian ini edema makula tidak dievaluasi, namun setelah dilakukan uji t pada data ditemukan bahwa pada penderita retinopati diabetika berat tajam penglihatannya lebih buruk dibanding penderita dengan retinopati diabetika ringan. Hal ini disebabkan karena banyaknya individu yang masuk kedalam kriteria PDR lanjutan. Dari segi usia, kadar GD1,2 dan lama menderita DM ternyata tidak didapatkan perbedaan antara retinopati diabetika ringan dan berat. Hal ini bisa juga dianggap bahwa sampel pada penelitian ini homogen. Jenis kelamin, perilaku merokok, dan perilaku diet tidak dievaluasi, namun secara deskriptif dapat dilihat pada Tabel 3,4, dan 5, tidak terdapat perbedaan yang berarti antara dua kelompok derajat retinopati diabetika.

\section{KESIMPULAN}

Terdapat hubungan yang signifikan antara $\mathrm{HbA} 1 \mathrm{c}$ dengan derajat berat retinopati diabetika. Tingginya kadar $\mathrm{HbA} 1 \mathrm{c}$ akan memberikan kemungkinan lebih besar untuk jatuh dalam keadaan retinopati diabetika derajat berat dengan cut-off $8,147 \%$. Tidak terdapat hubungan yang signifikan antara kadar lipid serum dengan derajat berat retinopati diabetika

\section{SARAN}

Dengan diketahui bahwa tingginya kadar $\mathrm{HbA} 1 \mathrm{C}$ meningkatkan tingginya derajat berat retinopati diabetika, maka diharapkan kita dapat mengendalikan kebutaan yang diakibatkan oleh beratnya retinopati diabetika secara tidak langsung. Hal ini dapat dilakukan dengan cara menjadikan pemeriksaan $\mathrm{HbA} 1 \mathrm{c}$ sebagai pemeriksaan standar untuk mengetahui kontrol kadar glukosa darah penderita DM, dan mengontrol kadarnya dibawah nilai cut-off.

\section{UCAPAN TERIMAKASIH}

Dana dari SPP/DPP Fakultas Kedokteran Universitas Brawijaya Malang

\section{DAFTAR KEPUSTAKAAN}

1. Sheetz MJ, King GL. Molecular understanding of Hyperglycemia's Adverse Effect for Diabetic Complications. JAMA 2002; 288: 2579-2586.

2. Suhendro Gatut. Pembentukan Sikatrik Retina Perifer pada Nonproliferatif Retinopati Diabetik untuk Mempertahankan Sistem Autoregulasi Retina Sentral. [Dissertation]. Surabaya; Universitas Airlangga; 1999.

3. American Academy of Opthalmology staff. In: International Opthalmology. Basic and Clinical Science Course. Section 12. San Francisco: American Academy of Opthalmology; 2003-2004; 185-187.

4. Valero, Sherma. Retinopathy Diabetic, Background.eMedicine 2001; 1-10

5. Delengocky, Tayson. Diabetic Retinopathy. Texas: TOMA By Laws Amandement meeting; 2003 Feb 7th ; 12-14.

6. DaSilva ZM, Freitas AM, Marcon, IM. Risk Factors Related To Severity of Diabetic Retinopathy. Arq Bras Opthalmol 2003; 66: 739-743. 
7. American Academy of Opthalmology staff. In: Retina and vitreus. Basic and Clinical Science Course. Section 12.San Francisco: American Academy of Opthalmology; 2003-2004; 70-86.

8. Kanski JJ. Retinal Vascular Disease. In: Kanski JJ, editor. Clinical Opthalmology. Vth ed. London: Butterworth Heinemann; 2003; 439-455.

9. Viswanath K, Muray DD. Diabetic Retinopathy: Clinical Findings and Management. Journal of Community Eye Health 2003; 16: 21-24.

10. Tapp RJ, Shaw JE, Harper CA, DeCourten MP, Balkau B, McCarthy DJ, Taylor HR; et al. The Prevalence of and Factors Associated with Diabetic Retinopathy in Australian Population. Diabetes Care 2003; 26: 1731-1737.

11. Benson WE, Tasman W, Duane TD. Diabetes Mellitus and the Eye. In: Tasman W, Jaeger EA, eds. Duane's Clinical Opthalmology: Disease of The Retina. Philadelphia: JB Lippincott Company; 1994; 1-25.

12. Gillow JT, Gibson JM, Dodson PM. Hypertension and diabetic retinopathy: What's the Story. Br J Opthalmol 1999; 83: 1083-1087.

13. VanLeiden HA, Dekker JM, Moli AC, Nijpels G, Heine RJ, Bouter LM; et al. Blood Pressure, Lipids, and Obesity are Associated with Retinopathy. Diabetes Care 2002; 25: 1320-1325.

14. Valero SO. Retinopathy, Diabetic, Proliferative.eMedicine 2001; 1-7.

15. Hammes HP, Lin J, Ranner O, Shani M, Lundqvist A, Betsholtz C; et al. Pericytes and the Pathogenesis of diabetic Retinopathy. Diabetes 2002; 51:3107-3112.

16. Radha V, Rema M, Mohan V. Genes and Diabetic Retinopathy. Indian J Opthalmol 2002; 50: 5-11.

17. Kinshuck David. What is the 'HbA1c?'(serial online) 2004 April; 1(1): (5 screen). Available from: http:/ /www.cdc.gov/cnnp.

18. Nathan DM. Relationship between Metabolic Control and Long Term Complications of Diabetes. In: Kahn CR, Weis GC, editors. Joslin's Diabetes Mellitus. 13 $3^{\text {th }}$ ed. Philadelphia: Lea \& Febiger; 1994: 36: 620-628.

19. West SK, Klein R, Rodriguez J, Munoz B, Broman AT, Sanchez R. Diabetes and Diabetic Retinopathy in a MexicanAmerican Population. Diabetes Care 2001; 24:1204-1209

20. Rohlfing CL, Wiedmeyer HM, Little RR, England JD, Tennill A, Goldstein DE. Defining The Relationship Between Plasma Glucose and HbA1c. Diabetes Care 2002; 25: 275-278.

21. Davidson JA. Rationale for More aggressive Guidelines for Diabetic Control. Endocrine practice 2002; 8: 37-39.

22. Levetan CS. Hemoglobin A1c: Need to Standarize Them. Endocrine practice 2002; 8: 25-26.

23. Chew EY, Ferris FL. Non Proliferative Diabetic Retinopathy. In: Stephen J Ryan, editor. Retina. $3^{\text {rd }}$ ed. St Louis: Mosby: 2001; 1295-1305.

24. Cioffi GA, Graustam E, ALM A. Ocular circulation. In: Kauffman PL, ALM Albert, editors. Adler's Physiology of The Eye. 10 th editor. St Louis: Mosby; 2003; 775.

25. Waspadji S. Cellular immune Respon among Diabetic and Factors Affecting the Development of Diabetic Retinopathy. In: Understanding of Ocular Diabetics. 2nd Continuing Opthalmology Education. Jakarta, Indonesia; 1999 November 2728;16-24

26. El Haddad OAW, Saad MK. Prevalence and Risk Factors for Diabetic Retinopathy among Omani Diabetics. Br J Opthalmol 1998; 82: 901-906.

27. Jusman SW. Basic Concepts of Biochemistry in Diabetes Mellitus.In : Understanding of Ocular Diabetics. $2^{\text {nd }}$ Continuing Opthalmology Education. Jakarta, Indonesia; 1999 November 27-28; 2-14

28. Leung GM, Lam KSL. Diabetic Complication and Their Implications of Health Care in Asia. Hong Kong Medical Journal 2000; 6: 61-68.

29. King GL, Banskota NK. Mechanisms of Diabetic Microvascular Complications. In: Kahn CR, Weis GC, eds. Joslin's Diabetes Mellitus. $13^{\text {th }}$ ed. Philadelphia: Lea \& Febiger; 1994; 37: 631-641.

30. Ciulla TA, Amador AG, Zinman B. Diabetic retinopathy and Macular Edema. Diabetes Care 2003; 26: 2653-2664.

31. Frank RN. Mechanisms in Diabetic Retinopathy. In: Stephen J Ryan, editor. Retina. $3^{\text {rd }}$ ed. St Louis: Mosby; 2001;12591287.

32. Donelly R, Smith AM, Gardner ID, Morris AD.Vascular Complication of Diabetes. BMJ 2000; 320: 1062-1066.

33. Standl Ebenhard. International Diabetes Federation European Policy Group Standards for Diabetes. Endocrine Practice 2002; 8: 37-38.

34. Su DHW, Yeo KT. Diabetic Retinopathy and serum Lipids. Singapore Med J 2000; 41: 295-297.

35. Tailor Anitaben, Granger DN. Hypercholesterolemia Promotes P-Selectin-Dependent Platelet-Endothelial Cell Adhesion in Postcapillary Venules. Arterioscle Thromb Vasc Biol 2003; 23:675-680

36. Glass CK, Witztum JL. Atherosclerosis: The Road Ahead. 2004. 
37. Lysons TJ, Jenkins AJ, Zheng D. Diabetic Retinopathy and Serum Lippoprotein subclasses in the DCCT/ EDIC cohort. Invest opthalmol . Vis Sci 2004; 45: 910-918.

38. Howard BV, Howard WJ. The Pathophysiology and Treatment of Lipid Disorders in Diabetes Mellitus. In: Kahn CR, Weis GC, editors. Joslin's Diabetes Mellitus. 13 ${ }^{\text {th }}$ ed. Philadelphia: Lea \& Febiger; 1994; 21: 372-381 